\title{
I Feel Less Judged, so I Speak More : \\ Introverted Students' Response on Online Learning Platforms in Speaking Class
}

\author{
Nuning Wahyu Astuti \\ IAIN Surakarta \\ e-mail:nuning.wahyu@,iain-surakarta.ac.id
}

Keywords:

Online Learning, Speaking,

Introverts

\begin{abstract}
A B S T R A C T
As one of the productive skills in English, speaking has always been associated with extroverted people. However, during this online learning, introverted students gain autonomy which allows them to express ideas freely. The article used a mixed-method strategy to collect data. The result revealed $70,33 \%$ of the total participants were introverted students. In answering the questionnaire, the participants agreed on six items, including activities in speaking class, confidence, interactions with lecturers and classmates, and assignment submission and disagreed on three items, including material delivery, engagement, and group discussion. The article serves as a basis for instructors, academicians, and researchers to provide the most suitable online learning platforms for all types of students.
\end{abstract}

\section{INTRODUCTION}

Due to the spread of Coronavirus in Indonesia, the government has taken immediate actions to overcome the crisis. On April 3, 2020, The Indonesian Ministry of Health (MOH) issued MOH Regulation No. 9 consisting Guidelines for Limitation of Large-Scale Social Interactions (Pembatasan Sosial Berskala Besar or PSBB). This regulation aims to further regulate the procedure for local governments in implementing PSBB in their regions, as stated by GR 21/2020. In response to this regulation, everyone is forced to remain at home and to start working and learning from home. Specifically, in the field of education, the United Nations Educational, Scientific and Cultural Organization stated that there are 1,186,127,211 learners, or about $67,7 \%$ of the total enrolled students from 144 countries were affected by this pandemic. These countries had to change their teaching and learning systems to prevent the virus outbreak (as cited in Rasmitadila et al. 2020).

Changing the teaching and learning system to online learning is the best solution to break the chain of virus outbreak (Mulenga and Marbán 2020). Toquero (2020) argues that health measures and educational planning in educational institution provide the students with a higher opportunity to study while preventing the spread of the virus. However, adapting and adjusting to a new teaching and learning method is easier said than done. In most Indonesian education institutions, online learning is not a common practice since both lecturers and students prefer face-to-face instead of distance/online lectures. The lack of trained human resources and limited access to internet service are two of the most common challenges the students face in accessing the learning materials. To overcome the challenge, lecturers are forced to provide an accessible learning platform and ensure all students receive their required learning materials. Free Software like Google Meet, Zoom and Facebook Live can be useful for online discussion.

This discussion session is necessary to clarify the students' concepts and additional queries related to the lecture. Using WhatsApp Group as an additional tool can be an effective way to 
share recorded lectures suppose revision and further understanding is needed. Implementing social networking applications and social media helps students with poor communication skills interact effectively with their lecturer compared to face-to-face lectures (Khan 2020).

One of the most challenging subjects for both lecturers and students during online learning is speaking. As the tool of communication, speaking requires interaction among participants to ensure the message is perfectly conveyed. Unfortunately, even in a face-to-face classroom situation, not all students can communicate fluently and accurately due to their lack of necessary knowledge. Among the factors influencing students' language learning are affective factors (Samand, Sailan, and Lio 2019). The affective factors, in this case, refer to the students' personality.

Further, Samand et al.(2019) define personality as the characteristics owned by an individual as reactions to social stimuli and social features of his/her environment. This argument is supported by Jung (cited in Samand et al. 2019), who states that extrovert is the type of people whose attention is directed outside of him/herself. In contrast, the introvert belongs to people whose attention are focused on themselves. Concerning oral communication, a sociable person or the extroverted one would favour the physical presence of other people. In contrast, the introverted one prefers fewer people to be present (Davis and Taft 1962). To unveil the correlation between students' characteristics and their preferred speaking environment, this paper will elaborate the response of introverted students towards online learning platforms used in speaking class.

\section{METHOD}

The method employed in this study is a mixed-method design to collect qualitative and quantitative data. As stated by Creswell (cited in Fitriani, Bandung, and Kadri 2020), the mixed-method design utilizes the strength of both qualitative and quantitative research to collect data. To collect the data, the writer applied a purposive sampling technique. The participants of this research are 37 students from the speaking class of the 2020 academic year, second semester from the English Education Department Program, IAIN Surakarta. There are two questionnaires distributed to the participants. The first questionnaire is to determine their characteristics. The second one is to gather their response to online learning platforms for speaking class. To collect qualitative data, the writer implemented an interview strategy.

\section{RESULTS AND DISCUSSION}

To determine the spectrum of students' characteristics, the writer distributed a questionnaire containing 20 items. The questions were formulated based on the characteristics of introversion often accepted by contemporary researchers (Cain 2013). Based on the questionnaire, the students are likely to be introverted students when most of their answers are "true". However, this does not mean that the questionnaire determines students' characteristics in all circumstances. As Jung (in Cain 2013, p. 14) stated, "There is no such thing as a pure extrovert or a pure introvert. Such a man would be in the lunatic asylum." The result of this questionnaire is that there are $70,33 \%$ of the total participants are introverted students. The results of students' responses are described below. 
Table 1. Results on Students' Responses on Online Learning Platforms

\begin{tabular}{|c|c|c|c|c|}
\hline No. & Topic & Question & Percentage & Category \\
\hline 1. & $\begin{array}{l}\text { Students' response in } \\
\text { understanding the } \\
\text { material }\end{array}$ & $\begin{array}{l}\text { Online learning platforms } \\
\text { help me understand the } \\
\text { materials better than } \\
\text { offline learning. }\end{array}$ & 54.8 & Disagree \\
\hline 2. & $\begin{array}{l}\text { Students' response on } \\
\text { the engagement in the } \\
\text { classroom }\end{array}$ & $\begin{array}{l}\text { Online learning is more } \\
\text { fun than offline learning. }\end{array}$ & 68.8 & Disagree \\
\hline 3. & $\begin{array}{l}\text { Students' preference } \\
\text { in the online learning } \\
\text { platform }\end{array}$ & $\begin{array}{l}\text { Which one do you think is } \\
\text { the most comfortable } \\
\text { online learning platform } \\
\text { for speaking? Voice Note, } \\
\text { Whatsapp, Google } \\
\text { Meet, Youtube? }\end{array}$ & 80.6 & $\begin{array}{l}\text { Voice Note } \\
\text { Whatsapp }\end{array}$ \\
\hline 4. & $\begin{array}{l}\text { Students' response on } \\
\text { daily activities in } \\
\text { speaking class }\end{array}$ & $\begin{array}{l}\text { I am more comfortable } \\
\text { speaking via online } \\
\text { learning platforms than in } \\
\text { front of the classroom. }\end{array}$ & 71 & Agree \\
\hline 5. & $\begin{array}{l}\text { Students' response on } \\
\text { motivation in } \\
\text { speaking }\end{array}$ & $\begin{array}{l}\text { Online learning platforms } \\
\text { motivate me to speak } \\
\text { more actively. }\end{array}$ & 45.2 & Agree \\
\hline 6. & $\begin{array}{l}\text { Students' response on } \\
\text { confidence in } \\
\text { speaking }\end{array}$ & $\begin{array}{l}\text { Online learning platforms } \\
\text { improve my confidence } \\
\text { in speaking. }\end{array}$ & 41.9 & Agree \\
\hline 7. & $\begin{array}{l}\text { Students' response on } \\
\text { group discussions }\end{array}$ & $\begin{array}{l}\text { I prefer online learning } \\
\text { than offline learning for } \\
\text { group discussions }\end{array}$ & 38.7 & Disagree \\
\hline 8. & $\begin{array}{l}\text { Students' response on } \\
\text { interactions } \quad \text { with } \\
\text { lecturers }\end{array}$ & $\begin{array}{l}\text { Speaking class via online } \\
\text { learning platforms help } \\
\text { me interact with the } \\
\text { lecturer easier. }\end{array}$ & 48.4 & Agree \\
\hline 9. & $\begin{array}{l}\text { Students' response on } \\
\text { interactions } \quad \text { with } \\
\text { classmates }\end{array}$ & $\begin{array}{l}\text { Speaking class via online } \\
\text { learning platforms help } \\
\text { me interact with my } \\
\text { classmates easier. }\end{array}$ & 45.2 & Agree \\
\hline 10. & $\begin{array}{l}\text { Students' response in } \\
\text { submitting } \\
\text { assignments }\end{array}$ & $\begin{array}{l}\text { In submitting } \\
\text { assignments for speaking, } \\
\text { I prefer online learning } \\
\text { platforms than offline } \\
\text { learning. }\end{array}$ & 64.6 & Agree \\
\hline
\end{tabular}

Based on the percentage shown in table 1, most students, regardless of their characteristics, prefer having face-to-face learning to understand the learning materials better. According to Glenn (2018), online learning workloads are larger than offline learning, and many 
students are not capable of managing their time. Students are required to understand the materials, but they are also burdened with online discussions, group projects, chapter summaries, and preparing for the multi-week individual. Therefore, it implies that students prefer to have offline classes to understand the materials as they can have direct interactions with their lecturers and classmates.

Table result number 2 indicates the lack of interests from students during an online classroom activity. Like the previous questions, apart from the larger workloads, another aspect affectingstudents' lack of interest is interaction with their peers. The feeling of isolation, solitude and the lack of personal attention and support affect students' failure in online or distance learning (Vayre and Vonthron 2017). From this table, it can be seen that though introverts' favour being alone to recharge their energy, they also cannot bear the feeling of isolation and solitude for a long time. Cain (2013) explains that introverts and extroverts equally need a companion as they complement one another; introverts are good listeners, and extroverts are good talkers. So, it implies how both introverted and extroverted students rely on one another to achieve their learning goals.

As indicated in table result number 3, Voice Note of Whatsapp Group still becomes the students' most comfortable online speaking class platform. During the interview, two students gave their reasons for selecting voice note of Whatsapp:

"It is because I live in Rural Area where signals are usually unstable. Especially when the lecturers explain their materials using conference call, I wouldn't be able to understand the materials as the voice is unclear." (Student A)

\section{"Whatsapp is the only app that has a good signal in my hometown" (Student B)}

Poor internet connectivity, lack of compatible devices, expensive data plans are some challenges faced by students during online learning (Rahman 2021)

Related to daily activities for speaking, table result number 4 shows that $71 \%$ of students prefer using online learning platforms. From the interview, it can be concluded that the students need extra time to think of what to say before they perform in front of their lecturers and friends.

"I feel less burdened when talking in front of the camera" (Student A)

"Yes, Miss, when speaking in front of my phone I can re-take as many times as I like, so I will make fewer mistakes" (Student C)

"My English is not that good, Miss, so I need more preparation before I speak" (Student D)

In terms of motivation, in table result number 5 , it can be seen that $45.2 \%$ of students admit they are motivated in speaking via online learning. The reasons are similar to the previous response, which is the longer preparation time for the speaking performance.

Table result number indicates that $41,9 \%$ of students admit they are more confident when speaking online than offline. The reasons include the more extended time allotment to think and the absence of eye contact, so they do not feel intimidated. In this case, offline learning allows them to speak freely without having to worry about their classmates' reactions towards their speaking ability. 
For doing group discussions, $38,7 \%$ of students chose offline learning as their preferred method of discussion. Cain (2013) further explains that collaborative work is beneficial for introverts, but it should occur in a small group. Besides, group work has become an essential part of the higher education (HE) degree curriculum (Walker 2007)

When it comes to interacting with lecturers, $48.4 \%$ of students admit online learning platforms allow them to interact easily with their lecturers. Students are forced to connect with their instructors via online learning, as their participation is vital to their classmates and instructors (Glenn 2018). Otherwise, there is no documented proof for learning to have occurred.

As shown in table result number $9,45,2 \%$ of students agree that they feel connected during speaking class via online learning. This may be due to the fact that they have never met since the first day of the teaching and learning process. Therefore, activities in speaking are medium to help them know and support each other. Glenn (2018) stated that studying in an online learning environment physically isolates learners from their lecturers and classmates, so a strong sense of empowerment is needed to help students succeed in learning via online platforms.

Similar to the students' response in doing daily activities via online platforms, most students also prefer submitting assignments on speaking through online learning platforms. The reasons for their preference are because they have more time to prepare their speaking and they feel less intimidated.

\section{CONCLUSION}

Despite many challenges encountered by students and instructors, online learning is still the best option during this crisis. This study focuses on the response of introverted students in speaking online class. Most students who are introverted agree that they are most comfortable with the new system. However, they still require more engagement and interactions with their peers and lecturers to avoid the feeling of isolation. In terms of material delivery, students' engagement, and group discussion, offline learning is still the best option for both introverted and extroverted students. This is due to the fact that those activities require direct interactions among their peers and lecturers to achieve the learning objectives. Further research is needed to explore suitable teaching and learning method to cater the needs of all characteristics of students. Besides, more studies are needed to understand what does and does not work in an online learning environment. Though lecturers can provide interactions through a conference call, the biggest challenge is still about how they build connections with the students and to make students understand that their lecturers are not some mystical entities at the other end of an internet connection. In a country like Indonesia, where people are struggling to achieve quality education, adapting to a new mode of learning is, of course, not an easy task. Poor internet connection, lack of proper environment at home, the significant cost of data plans, and students' comfort are some of the biggest challenges that the students need to deal with. In addition, institutions are also coping with this situation by trying to provide options to deal with this never sought circumstance. Now the concern is not about the quality of education but the delivery of education. To cater the needs of students with various characteristics and levels, educators should create innovative learning contents where a person-to-person connection is available, just like in a ground-based class. 


\section{REFERENCES}

Cain, Susan. (2013). Quiet: The Power of Introverts in a World That Can't Stop Talking. 1st ed. New York: Broadway Books.

Davis, D., \& Taft, R. (1976). A measure of preference for speaking rather than writing and its relationship to expressive language skills in adolescents. Language and Speech, 19(3), 224 235. https://doi.org/10.1177/002383097601900303

Fitriani, Yustina, Murti Bandung, and Mohtana Kharisma Kadri. (2020). "Humanitatis Journal of Language and Literature Students 'Perspective of Online Learning o n Speaking Class During Covid-19 Pandemic Humanitatis Journal of Language and Literature." Humanitatis Journal of Language and Literature 7(1):1-12.

Glenn, Cynthia Wheatley. (2018). "Adding the Human Touch to Asynchronous Online Learning." Journal of College Student Retention: Research, Theory and Practice 19(4):381-93.

Khan, Tahir Mehmood. (2020). "Use of Social Media and WhatsApp to Conduct Teaching Activities during the COVID-19 Lockdown in Pakistan." The International Journal of Pharmacy Practice 2020.

Mulenga, Eddie M., and José M. Marbán. (2020). "Prospective Teachers' Online Learning Mathematics Activities in the Age of COVID-19: A Cluster Analysis Approach." Eurasia Journal of Mathematics, Science and Technology Education 16(9).

Rahman, Afzalur. (2021). "Using Students' Experience to Derive Effectiveness of COVID-19Lockdown-Induced Emergency Online Learning at Undergraduate Level: Evidence from Assam, India." Higher Education for the Future 8(1):71-89.

Rasmitadila, Rusi Rusmiati Aliyyah, Reza Rachmadtullah, Achmad Samsudin, Ernawulan Syaodih, Muhammad Nurtanto, and Anna Riana Suryanti Tambunan. (2020). "The Perceptions of Primary School Teachers of Online Learning during the Covid-19 Pandemic Period: A Case Study in Indonesia." Journal of Ethnic and Cultural Studies 7(2):90-109.

Samand, Sri Muniarty, Zalili Sailan, and Asrun Lio. (2019). "Analysis On The Relationship Of Extrovert-Introvert Personality And Students' Speaking Performance In English Study Program Of Halu Oleo University." Journal of Language Education and Educational Technology (JLEET) 4(1).

Toquero, Cathy Mae. (2020). "Challenges and Opportunities for Higher Education amid the COVID-19 Pandemic: The Philippine Context." Pedagogical Research 5(4):em0063.

Vayre, Emilie, and Anne Marie Vonthron. (2017). "Psychological Engagement of Students in Distance and Online Learning: Effects of Self-Efficacy and Psychosocial Processes." Journal of Educational Computing Research 55(2):197-218.

Walker, Ann. (2007). "Group Work in Higher Education: Are Introverted Students Disadvantaged?" Psychology Learning \& Teaching 6(1):20-25. 